Published in final edited form as:

Clin Chest Med. 2015 December ; 36(4): 669-683. doi:10.1016/j.ccm.2015.08.009.

\title{
Ocular Sarcoidosis
}

Sirichai Pasadhika, MD and

Vitreoretinal and Uveitis Service, Legacy Devers Eye Institute, 1040 NW $22^{\text {nd }}$ Ave Suite 168, Portland, Oregon, USA

James T Rosenbaum, MD

Chief of Ophthalmology, Legacy Devers Eye Institute, Portland, Oregon, USA, jtrosenb@LHS.ORG

\section{Abstract}

Sarcoidosis is one of the leading causes of inflammatory eye disease. Ocular sarcoidosis can involve any part of the eye and its adnexal tissues, and may cause uveitis, episcleritis/scleritis, eyelid abnormalities, conjunctival granuloma, optic neuropathy, lacrimal gland enlargement and orbital inflammation. Glaucoma and cataract can be complications from inflammation itself or adverse effects from therapy. Ophthalmic manifestations can be isolated, or associated with other organ involvement. Patients with ocular sarcoidosis can present with a wide range of clinical presentations and severity. Multi-disciplinary approaches are required to achieve the best treatment outcomes for both ocular and systemic manifestations.

\section{Keywords}

sarcoidosis; eye; uveitis; dry eye; optic neuropathy; orbital inflammation

Sarcoidosis can involve almost any structure within or around the eye. In addition, the first recognized clinical manifestation of sarcoidosis often is eye disease. Both ophthalmologists and non-ophthalmologists need to be aware of the protean ocular manifestations of sarcoidosis.

\section{Epidemiology}

Ocular involvement of sarcoidosis has been known since the early 1900s, and has become more recognized since mid-1900s. ${ }^{1}$ Variability in the diagnostic criteria has made epidemiologic studies of ocular sarcoidosis challenging.

The prevalence of ocular involvement in different series ranges widely from 13\% (Turkish study) to $79 \%$ (Japanese study) of patients with systemic sarcoidosis. ${ }^{2-4}$ Ocular involvement is the presenting symptom in approximately 20-30\%., 6 Uveitis was reported in 30-70\%, and conjunctival nodules were found in $40 \% .^{2}$ In patients with systemic sarcoidosis, females

Corresponding author spasadhi@LHS.ORG, Phone: (503) 413-7022; Fax: (503) 413-7006.

Dr. Pasadhika has no conflict of interests to disclose.

Dr. Rosenbaum is a consultant for Abbvie, UCB, Genentech, Medimmune, Xoma, Portage, Auventx, Santen, Sanofi, and Regeneron. 
(56\%) are more likely to develop ocular involvement compared to males (23\%) in a study of 121 patients with biopsy-proven sarcoidosis. ${ }^{6}$

Sarcoidosis reportedly may affect children, and most of those cases begin between the ages of 8 and 15 years. ${ }^{7}$ Many patients, however, previously diagnosed as having early onset sarcoidosis are now recognized as having Blau syndrome with de novo mutations. ${ }^{8}$ Age distributions of ocular sarcoidosis in adults are bimodal. Two peaks of incidence are 20-30 years and 50-60 years. ${ }^{2}$ The mean age at presentation of uveitis is 42 years (range, 4-82). ${ }^{9}$ African Americans with biopsy-proven sarcoidosis have a higher likelihood to develop ocular involvement compared to Caucasians. ${ }^{10}$ Race may also influence the age of onset of uveitis. Blacks tend to develop uveitis at the mean age of 35-44 years, while whites are more likely to have uveitis at the mean age of $43-52$ years.., 11

Sarcoidosis accounted for approximately $1-3 \%$ of pediatric uveitis in referral centers, ${ }^{12}, 13$ while approximately $10 \%$ of adult uveitis was found to be associated with sarcoidosis. ${ }^{14,15}$ An epidemiologic study in the southeastern United States showed that sarcoidosis was the cause of uveitis in 11\% of the studied population (385 patients: $67 \%$ Caucasian, $31 \%$ African American). Subgroup analysis demonstrated that sarcoidosis accounted for $25 \%$ of uveitis among the African American patients. ${ }^{15}$

The majority of sarcoid uveitis is bilateral, and approximately $90 \%$ are chronic. ${ }^{9}$ The prevalence of uveitis subtype based on anatomical location varies among different studies, partly due to different terminologies used. Dana et al reported that, of 112 eyes with sarcoid uveitis, $28 \%$ were anterior, $38 \%$ were intermediate, $12 \%$ were posterior, and $22 \%$ were panuveitis. ${ }^{9}$ A Turkish study reported $46 \%$ as intermediate, $15 \%$ as anterior, and $38 \%$ as panuveitis. ${ }^{16}$ Another study from Japan described $75 \%$ with iritis and $67 \%$ with retinal vasculitis. ${ }^{4}$

The rate of sarcoidosis in patients with multifocal chorioretinitis is variable due to different diagnostic criteria and the extent of investigations among different studies. A study by Abad et al of 37 patients with multifocal chorioretinitis demonstrated a prevalence (68\%) of biopsy-proven and presumed sarcoidosis, ${ }^{17}$ while Ossewaarde-Van Norel at el reported a $39 \%$ rate. ${ }^{18}$ Of note, $62 \%$ of patients in the former study received a chest CT scan, ${ }^{17}$ but only $26 \%$ did in the latter. ${ }^{18}$

A Case Control Etiologic Study of Sarcoidosis (ACCESS) presented evidence for the allelic variation at the HLA-DRB1 locus as a significant contributing factor for sarcoidosis. HLADRB1*0401 allele was associated with ocular involvement in both blacks and whites (odds ratio 3.49$).{ }^{19}$

\section{Clinical manifestations of ocular sarcoidosis}

Ocular disease may be the initial manifestation in patients with sarcoidosis, and may cause severe visual impairment. The involvement may be characterized by granulomatous inflammation which can affect any part of the eye and its adnexa. Examples of the clinical presentations of ocular sarcoidosis are listed in Table 1. The most common ocular manifestations are uveitis, dry eye and conjunctival nodules. 


\section{- Uveitis and fundoscopic abnormalities}

Uveitis is the term used to describe an inflammation of the uveal tissues which are composed of the iris, ciliary body and choroid. Uveitis commonly affects tissue or space adjacent to the uvea such as the anterior chamber, vitreous humor, or retina. Uveitis is most commonly classified by anatomical location of the observed inflammation using slit-lamp biomicroscopy and fundus examination. Uveitis associated with sarcoidosis can present as anterior, intermediate, posterior or panuveitis. The most universally accepted uveitis classification, grading and terminologies are published by the Standardization of Uveitis Nomenclature (SUN) Working Group. ${ }^{20}$

In fact, sarcoidosis is well known as a cause of granulomatous inflammation. One can be easily confused by multiple authors who state that sarcoid uveitis can be presented as either "nongranulomatous" or "granulomatous" uveitis. These clinical pathologic terms are essentially misnomers, as they do not represent actual histopathological studies. "Granulomatous" uveitis is used when at least one of the following clinical signs are observed: 1) large mutton-fat keratic precipitates (KPs) (accumulation of inflammatory leukocytes that deposit on the corneal endothelium), 2) iris or trabecular meshwork nodules, or 3) choroidal granuloma. It is not uncommon that typical cases of sarcoid uveitis present with at least one of these findings. However, these signs may not be observed in all of the cases, especially those with early onset, those with less severe inflammation, or those who have been successfully treated. On the other hand, these signs are not specific for sarcoid uveitis, as they may be noticed in uveitis related to other causes, such as infections. The study of 112 eyes with sarcoid uveitis depicted $81 \%$ with granulomatous pattern. ${ }^{9}$

Anterior chamber inflammation is perhaps the most common sign of sarcoid uveitis. It was detected in 42 (91\%) of 46 patients with biopsy-proven sarcoid uveitis in one study. ${ }^{1}$ Of those 42 patients, 16 (38\%) had inflammation only in the anterior chamber, without posterior segment involvement. ${ }^{1}$ Typical clinical presentations in patients with acute anterior chamber inflammation may include redness, decreased vision, eye pain and photophobia. The degrees of inflammation may be variable from mild to very severe. However, the development of hypopyon (pus in the anterior chamber) is unlikely. ${ }^{21}$ Pain can be caused by ciliary spasm or elevated intraocular pressure (IOP). IOP elevation can be secondary to an obstruction of trabecular meshwork by a large amount of inflammatory leukocytes, trabecular meshwork nodules and inflammation, or peripheral anterior synechiae (adhesion of the peripheral iris to the peripheral cornea preventing aqueous outflow through the trabecular meshwork in the affected area). In cases with moderate and severe inflammation, posterior synechiae (adhesion of the iris to the anterior lens capsule) may form and cause an irregular and poorly dilated pupil which may prevent detailed examination of the posterior segment. Iris nodules are generally associated with moderate or severe inflammation. Without appropriate treatment, severe anterior uveitis can lead to anterior segment deformity and predispose to cataract formation. However, mild sarcoid uveitis may also be insidious in onset, and the patients can be asymptomatic. The diagnosis may only be discovered on screening or routine ocular examination. Early detection is crucial to potentially prevent sequelae from chronic inflammation. 
Intermediate uveitis is also a common presentation of ocular sarcoidosis. The patients may complain of floaters and/or blurry vision. Vitreous opacity and cystoid macular edema (CME) are the leading causes of decreased vision in patients with intermediate uveitis. Pars plana exudates and accumulation of white blood cells and vitreous debris on the retinal surface may be characterized as snow banks and snow balls (also called, string of pearls) on examination. Neovascularization of the optic disc and peripheral retina can also complicate peripheral retinal involvement, ${ }^{22}$ and can lead to vitreous hemorrhage in the minority of cases.

In sarcoid posterior uveitis, the retinal lesions usually accompany choroidal inflammation; however, either retinal or choroidal involvement can be isolated (Figure 1). Posterior involvement is generally bilateral, but can be largely asymmetric. Choroidal granuloma(s) may be unifocal or multifocal, and may vary in size from small (Dalen-Fuchs-like nodules or sarcoid spots) to large (may simulate choroidal tumors). ${ }^{23,24}$ Peripheral granulomas are unlikely to cause visual disturbance, but central lesions may lead to severe visual impairment. Choroidal neovascularization can develop in such lesions. ${ }^{25}$ Multifocal choroiditis related to sarcoidosis can present with fundoscopic findings very similar to those seen in birdshot chorioretinopathy. ${ }^{26}$ Exudative retinal detachment can rarely be seen in patients with ocular sarcoidosis, particularly those with large chorioretinal granulomas. Treated or inactive lesions may be noticeable as multifocal peripheral small punched-out chorioretinal scars similar to those observed in idiopathic multifocal choroiditis. Retinal pigment epithelial changes are observed in many cases, but do not usually cause visual loss. ${ }^{22}$ However, extensive involvement in the posterior pole may cause severe permanent visual disability (Figure 2).

Perivascular sheathing is a common finding representing retinal vasculitis associated with ocular sarcoidosis. Midperipheral periphlebitis is characteristic. In severe forms with scattered whitish-yellow perivascular retinal exudates along the retinal veins, the perivascular exudates have been described as "candle-wax drippings". ${ }^{24}$ Generally, periphlebitis in ocular sarcoidosis is not associated with significant vascular occlusion. However, occlusive retinal vascular diseases, such as branch and central retinal vein occlusion, have been reported. Intraretinal hemorrhages and retinal or optic disc neovascularization with subsequent vitreous hemorrhage may complicate retinal vasculitis secondary to sarcoidosis.

CME is a common cause of vision loss in patients with sarcoid uveitis. It may accompany severe active inflammation or retinal vasculitis in the posterior pole. It generally responds to corticosteroid therapy. Epiretinal membrane formation can also occur.

It has been reported that an incidence of central nervous system involvement is increased from $2 \%$ to $37 \%$ when fundoscopic abnormalities of ocular sarcoidosis are observed in one study. ${ }^{24}$ However, another study did not find such an association. ${ }^{22}$

\section{- Optic nerve involvement and neuro-ophthalmic manifestations}

Neurosarcoidosis is sometimes called "the great imitator" since it can cause nonspecific and variable symptoms simulating many other conditions. The symptoms are associated with the 
location of granuloma formation and related inflammatory sequelae. These symptoms may include decreased vision or visual field defects secondary to involvement of the optic nerve and its visual pathway, papilledema (see below) secondary to increased intracranial pressure, abnormal eye movement, pupillary abnormalities, visual hallucinations, encephalopathy, vasculopathy, peripheral neuropathy, myopathy, seizure, aseptic meningitis, hydrocephalus, spinal cord involvement and psychiatric symptoms. ${ }^{27}$

Cranial neuropathy is the most frequent manifestation of neurosarcoidosis. The most commonly affected nerves are the optic and facial nerves. ${ }^{28}$ Involvement of the optic nerve may be visible as the optic nerve granulomas or nodules, optic disc edema or optic atrophy. Besides resulting from increased intracranial pressure secondary to space occupying lesions or hydrocephalus, optic disc edema can be associated to either severe posterior uveitis or periphlebitis, or direct involvement of the optic disc, nerve, or nerve sheath by granulomatous tissue. ${ }^{29}$ Irreversibly impaired visual acuity occurs in more than half of those with direct optic nerve involvement. ${ }^{30}$ Facial paresis is a classic manifestation. It was believed to be related to either inflammation in the parotid gland, a result from a meningitic reaction, or direct compression. ${ }^{30}$ Lower motor neuron facial nerve paresis can cause ipsilateral poor eyelid tone and closure, which may lead to exposure keratopathy, epiphora and ectropion. Severe surface abnormalities can progress to corneal ulcers with permanent blindness.

Acquired abnormal ocular movements such as nystagmus may be observed in neurosarcoidosis. ${ }^{31}$ Pupillary abnormalities, such as a relative pupillary defect and light-near dissociation, as well as visual hallucinations have been reported in sarcoidosis with central nervous system involvement. ${ }^{32}$

\section{- Eyelid and ocular surface disease}

Dermatologic manifestations of sarcoidosis are well-known. Partial- or full-thickness involvement of the eyelid may be seen. Periorbital erythematous eyelid swelling can be present as the only sign of ocular sarcoidosis. ${ }^{33,34}$ Erythematous eyelid mass lesions may vary in size from small papules ${ }^{35}$ to a large mass which may mimic eyelid tumors or cutaneous scars. ${ }^{36}$ Collins et al reported a case of a 50-year-old female with systemic sarcoidosis, including pulmonary, dermatologic and articular symptoms. The patient had chronic eyelid nodules which subsequently caused eye irritation and eyelid deformities with mucocutaneous notching. She had extensive scarring of the posterior lamella causing entropion and trichiasis. The patient underwent full-thickness wedge resection to treat eyelash malposition. Histopathological study showed full-thickness noncaseating granuloma of the eyelid. ${ }^{37}$ A similar case was reported by Moin and coworkers in a 43-year-old African American man. The patient had distorted eyelid architecture with madarosis, marked forniceal foreshortening and symblepharon. Eyelid, conjunctiva and facial skin biopsies demonstrated noncaseating granulomatous inflammation. Extensive destruction of the eyelid was partially treated with corticosteroids and methotrexate, prior to undergoing reconstruction surgery. ${ }^{38}$ Rarely granulomatous inflammation may selectively involve small eyelid structure such as the Müller muscle, and such lesion may cause eyelid retraction which is far more commonly seen in patients with thyroid orbitopathy. ${ }^{39}$ 
Conjunctival involvement is common, but may be overlooked as most conjunctival lesions are asymptomatic. Most typical conjunctival nodules are observed at the palpebral conjunctivae; however, they may also be located at the bulbar or perilimbal areas. ${ }^{40}$ Early lesions may present as multiple, white, discrete bulbar conjunctival deposits. ${ }^{41}$ Some patients may have significant redness and irritation, and present as acute follicular conjunctivitis. ${ }^{42,43}$ Cases with chronic cicatricial conjunctivitis with progressive scarring and symblepharon have also been reported. ${ }^{44,45}$ Large conjunctival granuloma may simulate conjunctival tumors. ${ }^{46}$

Scleritis is uncommonly associated with sarcoidosis, but sarcoidosis should be considered in the differential diagnosis of scleritis. Sarcoidosis-associated scleritis may present as anterior diffuse, ${ }^{47}$ anterior nodular, ${ }^{47-49}$ or posterior scleritis. ${ }^{50}$ All of the reported cases were women with ages ranging from 53 to 64 years old ${ }^{47-49}$ which were on average older than most patients with sarcoid uveitis, except one patient (42-year-old man) with posterior scleritis who also had annular ciliochoroidal effusion. ${ }^{50}$ Sarcoidosis-associated scleritis is more likely non-necrotizing, and tends to respond well to oral corticosteroids. A clinicopathologic study of 55 patients who were diagnosed with necrotizing scleritis showed that only one patient (1.8\%) had sarcoidosis. Although the patient presented clinically as necrotizing scleritis, the biopsy demonstrated discrete non-necrotizing granulomatous inflammation. ${ }^{51}$

The cornea can also be affected by ocular sarcoidosis. The most common corneal involvement is superficial punctate keratitis secondary to keratoconjunctivitis sicca (KCS; dry eye). The patients with chronic inflammation may have peripheral band opacities resulting from calcium deposits on the Bowman's subepithelial layer, or so called band keratopathy. ${ }^{1}$ Interstitial keratitis was also reported as a presenting sign of ocular sarcoidosis along with an evidence of posterior uveitis and optic disc edema. The patient was subsequently diagnosed with sarcoidosis by transbronchial biopsy two years thereafter. ${ }^{52}$ Peripheral ulcerative keratitis leading to corneal perforation was also described in a 42-yearold woman in one report. ${ }^{53}$

\section{- Lacrimal system and keratoconjunctivitis sicca (KCS)}

The lacrimal gland is the most common organ in the orbit affected by sarcoidosis. Histopathological studies of biopsy-proven orbital sarcoidosis revealed the main lacrimal gland involvement in 42-63\%. ${ }^{54-56}$ Patients with lacrimal gland involvement may or may not be symptomatic. If there is significant enlargement of the lacrimal gland, they may present with palpable mass or other symptoms due to mass effects. Typical characteristic features on computerized tomography (CT) are diffuse enlargement of the gland with homogenous enhancement. ${ }^{54}$

KCS has long been recognized as a common consequence of sarcoidosis. ${ }^{57}$ Dry eye syndrome in sarcoidosis is believed to be related primarily to lacrimal gland inflammation/ infiltration that results in decreased aqueous tear production. Most studies reported abnormal imaging and biopsy results of the main lacrimal gland, but to our knowledge none has specifically mentioned an involvement of the accessory lacrimal glands. However, fullthickness eyelid skin involvement has been reported. ${ }^{37}$ Physiologically, the main lacrimal 
glands located at the anterolateral part of the orbit are responsible mainly for reflex tear secretion, while the small accessory lacrimal glands in the eyelid and conjunctivae produce the majority of basal tear. This knowledge may imply that both the main and accessory lacrimal glands may be affected in those with severe dry eye associated with sarcoidosis. KCS may cause irritation, tearing, corneal epitheliopathy, corneal abrasion, infection and permanent corneal scars.

The tear is drained via the puncta through the canaliculi, nasolacrimal sac and duct into the nasal meatus. Granulomatous inflammation due to sarcoidosis may directly affect the lacrimal drainage system causing lacrimal obstruction and lead to symptomatic epiphora (excessive tearing). ${ }^{58,59}$

\section{- Orbital involvement}

Besides the lacrimal gland, sarcoidosis can also involve other orbital structures, including orbital fat, extraocular muscles and the optic nerve sheath. ${ }^{54}$ Histopathological studies showed that the main complaints of patients with orbital sarcoidosis requiring orbital biopsy are palpable mass and eyelid swelling. ${ }^{54-56}$ Other symptoms included ptosis, globe displacement, proptosis, redness, pain, vision loss, tearing and diplopia. Age ranged between 18 and 83 years old, with mean age of approximately $45-55$ years. The majority of the patients were female. Concurrent systemic sarcoidosis was reported in 34-50\% of biopsyproven orbital sarcoidosis. ${ }^{54,56}$ The lesions were well-circumscribed in $85-90 \%$, with $10-15 \%$ of diffuse or infiltrative patterns. The lesions were solid, but rarely cystic. ${ }^{56}$ The majority of the lesions are located in the anterior orbit, especially anteroinferior. ${ }^{55}$ Orbital mass secondary to sarcoidosis can cause central retinal artery occlusion leading to permanent blindness. ${ }^{60}$

\section{- Glaucoma and cataract}

Elevated IOP is common in patients with sarcoid uveitis. A retrospective study in 1986 reported a high rate of severe visual loss (vision of 20/200 or worse) in 8 of 11 patients with concurrent sarcoid uveitis and glaucoma. ${ }^{61}$ Ocular hypertension and glaucoma may result from trabecular meshwork dysfunction due to edema or obstruction from inflammatory cells. Severe or chronic anterior chamber inflammation may cause angle closure glaucoma secondary to peripheral anterior synechiae formation. A Japanese study revealed a high incidence of abnormal gonioscopic findings (61\% trabecular nodules and 55\% tent-like peripheral anterior synechiae) among 159 patients with systemic sarcoidosis. ${ }^{4}$ Patients with uveitic glaucoma have a significant risk of surgical failure when requiring a filtering procedure. ${ }^{62}$ Elevated IOP can also be related to orbital mass effects or side effects from corticosteroid therapy.

Cataract formation is also common in patients with sarcoid uveitis and leads to visual loss. Any form of corticosteroid therapy, including topical, regional or systemic corticosteroids, can cause cataract and ocular hypertension. 


\section{Diagnosis of ocular sarcoidosis}

Sarcoidosis is one of several conditions that may simultaneously involve multiple ocular tissues with various presentations. For example, patients may present with acute anterior uveitis with lacrimal gland enlargement, bilateral multifocal choroiditis with conjunctival nodules, or peripheral ulcerative keratitis with orbital inflammation. Sarcoidosis should be particularly high on differential diagnoses in those with involvement of multiple ocular tissues.

The gold standard for the diagnosis of sarcoidosis is a tissue biopsy. The most common biopsy samples are retrieved from the lungs, lymph nodes, skin, conjunctivae, lacrimal glands or orbital tissues. However, suspected lesions may not be easily accessible, and biopsy may not be a desirable diagnostic choice from the patient standpoint. The lungs and hilar lymph nodes are the most commonly affected organs. Therefore, imaging studies, including a chest $\mathrm{x}$-ray, a chest $\mathrm{CT}$ scan, and occasionally gallium scintigraphy, may help aid the diagnosis. Some patients with sarcoidosis may have elevated serum levels of calcium, angiotensin converting enzyme (ACE) and/or lysozyme.

The diagnostic criteria for ocular sarcoidosis vary among different experts. In 2009, the first International Workshop on Ocular Sarcoidosis (IWOS) published the international criteria for the diagnosis of ocular sarcoidosis which aimed for universal use. ${ }^{63}$ The members of the IWOS identified 7 clinical signs suggestive of ocular sarcoidosis, 5 laboratory investigations in suspected ocular sarcoidosis, and 4 diagnostic terms for ocular sarcoidosis. (Table 2)

The clinical signs listed are useful for the diagnosis of sarcoid uveitis. However, the IWOS did not discuss the criteria for diagnosis of ocular adnexal involvement that was mainly diagnosed based on histopathological studies of the accessible lesions. In our practice, we generally start with a chest X-ray, and reserve a chest CT scan for highly suspicious patients or for whom the diagnosis may change their therapy. Due to the amount of radiation, we are less likely to order chest CT scans for younger patients. Elevated serum levels of calcium, ACE or lysozyme alone are usually neither sensitive nor specific for the diagnosis.

Conjunctival biopsy is a simple and useful procedure when patients present with conjunctival nodules or prominent follicles. Careful examination may reveal these findings. There is largely disagreement regarding the yield of random conjunctival biopsy in those without visible conjunctival lesions. In various studies the rate of positive random biopsy results ranged from 20 to $71 \%$ in patients with positive biopsy from other sites, and from 1 to $28 \%$ in those with clinically suspected sarcoidosis without histological confirmation. ${ }^{1,64-66}$ Nichols et al reported 55\% positive conjunctival biopsy rate in patients with biopsy-proven sarcoidosis from other tissues, but only $1 \%$ positive rate in those with negative systemic biopsy. From this study, a strip of conjunctival tissue at least 3 by $10 \mathrm{~mm}$ in size each was removed from the inferior cul-de-sac of both eyes. The authors found no association between an incidence of anterior uveitis and a positive conjunctival biopsy. ${ }^{64}$ The presence of conjunctival follicles may slightly increase the likelihood of a positive biopsy. Crick et al demonstrated 20\% positive conjunctival biopsy rate in biopsy-proven sarcoidosis, and the rate was increased to $37 \%$ in those with conjunctival follicles. ${ }^{1}$ In our 
practice, we reserve a conjunctival biopsy only for those with visible conjunctival nodules on exam.

Several non-invasive diagnostic imaging techniques have been studied in patients with ocular sarcoidosis. In-vivo confocal microscopy of the conjunctiva was successfully used to identify the presence of multinucleated giant cells in patients with sarcoid conjunctival nodules with $100 \%$ specificity and $50 \%$ sensitivity. ${ }^{67}$ The procedure required technical skills and may need an instrument with high resolution and deep penetration ability to improve a sensitivity of the test. Rose-Nussbaumer et al recently reported that anterior segment spectral-domain optical coherence tomography (OCT) could differentiate a predominantly mononuclear pattern of anterior chamber cells in active anterior uveitis associated with sarcoidosis or inflammatory bowel disease from a predominantly polymorphonuclear pattern in HLA-B27-related uveitis. ${ }^{68}$ Güngör et al revealed that patients with quiescent sarcoid posterior uveitis may have decreased choroidal thickness measurements compared to normal controls using an enhanced depth imaging OCT. ${ }^{69}$

Our group previously studied microarray analysis of gene expression on peripheral blood, lung and lymph node, and found that patients with sarcoidosis (with or without uveitis) had significant increases in STAT1 and STAT1-regulated chemokines compared to normal controls. STAT1 is a transcription factor. It can be activated by interferons which contribute to granuloma formation and which occasionally cause granulomatous adverse reactions. ${ }^{70}$ The STAT1 upregulated pattern was not observed in patients with ankylosing spondylitis (with or without uveitis). ${ }^{71}$ Subsequent gene expression study on conjunctival granuloma tissues showed that the activated form of STAT1 was more frequently detected in sarcoidosis patients; however, the activity of STAT1-regulated genes may not be specific to only sarcoidosis as STAT1 may also express on other conjunctival granulomatous diseases. ${ }^{72}$ More recently we have analyzed the gene expression pattern from either the lacrimal gland or orbital adipose tissue affected by sarcoidosis. ${ }^{73}$ This study confirmed an increased expression of STAT1 and showed that similar transcripts are elevated in the blood and solid tissue from patients with sarcoidosis. ${ }^{73}$

\section{Treatment of ocular sarcoidosis}

The primary aims for management of ocular sarcoidosis are to restore vision and to prevent complications from related inflammation. Corticosteroid therapy, including topical, regional and systemic routes, is the mainstay of treatment. Other immunomodulators may be required in some patients who are dependent, unresponsive, or intolerant to corticosteroid treatment.

\section{- Treatment of sarcoid uveitis}

1. Topical corticosteroids-The most commonly used topical corticosteroid for anterior uveitis is prednisolone acetate. Its dosage can be titrated based on the degree of anterior chamber inflammation from once daily to hourly. The relatively new medication, difluprednate, generally is more potent. Difluprednate $0.05 \%$ given 4 times daily may be at least as effective as prednisolone acetate $1 \% 8$ times daily for the treatment of anterior uveitis. ${ }^{74}$ Their side effects are dose-dependent, with the most concern to cause elevated IOP and cataract progression. 
Topical corticosteroid drops are used primarily to treat anterior chamber inflammation, but typically are insufficient to control posterior segment inflammation. However, it may be effective to treat CME associated with florid anterior uveitis.

2. Topical cycloplegics-Cycloplegic eye drops are helpful to relieve pain from ciliary spasm and to break or prevent posterior synechiae which are common in patients with moderate and severe anterior chamber inflammation. Shorter acting medications such as cyclopentolate $1 \%$ are generally used in the acute case, and longer acting agents such as atropine $1 \%$ may be given in those with chronic or severe anterior chamber inflammation.

\section{Regional corticosteroid injections and implants-Regional corticosteroid} injections and implants can be considered in uveitis associated with posterior segment involvement or when a patient is poorly responsive or noncompliant to frequent topical corticosteroids. The depot injections can be given periocularly or intravitreally.

Periocular injections can be performed using either a transcutaneous or transconjunctival route, and either a superior or inferior approach. In our practice, an orbital floor injection is typically given through the inferolateral eyelid skin. The most commonly used medication is triamcinolone acetonide 20-40 mg. Examples of other alternatives are betamethasone and methylprednisolone, which both have a shorter duration of effect compared to triamcinolone acetonide. The injection can be repeated as soon as 4-6 weeks after the initial therapy.

Intravitreal triamcinolone acetonide (1-4 mg) injections may be given, especially when periocular injections inadequately control inflammation. The effects may last 3-6 months after each injection. The patients need to be monitored carefully for elevated IOP. The procedure can be performed in clinic under topical or subconjunctival anesthesia.

A biodegradable intraocular implant containing 700 micrograms of dexamethasone given through a 22-gauge applicator has been approved for the treatment of uveitis involving the posterior segment of the eye. A study of its efficacy and safety for persistent uveitic CME showed that a single dexamethasone implant was effective to improve vision and macular edema in the majority of the patients. However, recurrence of CME can be observed in approximately $65 \%$ of the patients at 6 months. ${ }^{75} \mathrm{~A}$ study comparing intravitreal triamcinolone injections with dexamethasone implants in CME secondary to retinal vein occlusion demonstrated similar outcomes and similar incidence of side effects. ${ }^{76}$

A sustained-release fluocinolone acetonide implant has been approved in the US for chronic noninfectious posterior uveitis. The implant is inserted surgically into the vitreous cavity through a scleral incision, and may release drug for a median period of 30 months. It is effective to control inflammation in the majority of implanted eyes, ${ }^{77}$ but it is associated with high rate of complications, especially elevated IOP and cataractogenesis. Approximately $37 \%$ of the implanted eyes needed glaucoma surgery in a 3-year follow up study. ${ }^{78} \mathrm{~A}$ cost-effective study revealed that a fluocinolone implant was reasonably costeffective compared to systemic immunosuppressive agents in patients with unilateral disease, but not for those who need bilateral implants. ${ }^{79}$ 
4. Systemic corticosteroids-Systemic corticosteroids are used in patients with severe bilateral uveitis, when topical and/or regional therapy is insufficient to control inflammation, or when the systemic disease also requires therapy. Systemic corticosteroid therapy generally is rapidly effective, but a high dose such as $60 \mathrm{mg}$ of prednisone daily should be used for a limited duration to avoid both ocular and systemic adverse effects. Prednisone is the most commonly used oral corticosteroids in the United States. It is typically prescribed $1-1.5 \mathrm{mg} / \mathrm{kg} /$ day initially, and tapered gradually to avoid relapse. Short-term intravenous methylprednisolone is sometimes given in patients with vision-threatening retinal or optic nerve lesions, followed by oral prednisone.

5. Systemic immunosuppressive agents-Systemic immunosuppressive agents are indicated in patients who are corticosteroid-dependent or -intolerant. A low dose of prednisone such as $5 \mathrm{mg}$ per day may be preferable to an immunosuppressant. In some circumstances, patients may have already received a systemic immunosuppressant to control their systemic manifestations of sarcoidosis. Anti-metabolites ${ }^{80,81}$ and calcineurin inhibitors ${ }^{82,83}$ have been studied for the treatment of sarcoid-related ocular inflammation. Examples and dosage of systemic immunosuppressive drugs that may be used for the treatment of non-infectious uveitis are listed in Table $3 .{ }^{84}$ The most commonly used medications for chronic eye inflammation including ocular sarcoidosis are methotrexate, ${ }^{85}$ mycophenolate mofetil, ${ }^{86}$ azathioprine ${ }^{87}$ and cyclosporine. ${ }^{88}$

6. Biologic agents-Biologics are relatively novel treatment for refractory noninfectious uveitis. The knowledge on ocular indications is mainly based on case reports and series, with the minority of evidence from several non-randomized trials and one randomized double-masked trial. ${ }^{89}$ To date, biologic agents studied for the treatment of uveitis related to sarcoidosis are Tumor Necrosis Factor (TNF)-a inhibitors, including infliximab, adalimumab, etanercept and golimumab.

Infliximab has been reported as an effective immunosuppressive agent in most patients with refractory uveitis related to multiple causes in a prospective trial. ${ }^{90}$ However, limited data revealed mixed results on its efficacy to control ocular inflammation in sarcoid uveitis in particular. Suhler et al prospectively enrolled 31 patients with refractory uveitis for infliximab therapy as a concomitant immunosuppressant. Three out of the 31 patients were diagnosed with sarcoid panuveitis. All of the 3 patients had improved visual acuity after infliximab therapy, but none of them showed an ability to completely control inflammation or to reduce doses of concomitant prednisone and immunosuppressive treatment by half. ${ }^{90,91}$ In contrast, all 4 patients with sarcoid uveitis from different series ( 2 of Pritchard et al's, ${ }^{92} 1$ of Doty et al's, ${ }^{93}$ and 1 of Benitez-del-Castillo et al's ${ }^{94}$ ) had resolution of ocular inflammation several weeks after infliximab therapy, but needed continuation of infliximab infusions every 4-8 weeks to prevent relapse.

Erckens and coworkers studied the use of adalimumab as an adjunctive therapy in 41 eyes of 26 patients with refractory posterior sarcoidosis secondary to sarcoidosis. Eighty-five percent of the cases showed improvement of intraocular inflammatory signs, while $15 \%$ had stable outcomes. The improvement of intraocular inflammation included resolution of vasculitis, choroidal involvement, papillitis, macular edema and vitreous haze in the 
majority of the patients who had the respective signs at baseline. ${ }^{95}$ A study from our group also showed that all 6 patients with sarcoid uveitis, out of 31 patients with various uveitic diagnoses, were defined as clinical responders at 10 weeks by demonstrating either improvement of visual acuity, ocular inflammation, angiographic findings or an ability to taper medications. At 50 weeks, 3 patients $(50 \%)$ retained clinical success, while the others had secondary failure (1 due to loss of efficacy, 1 due to failure to taper corticosteroids, and 1 due to lost to follow up). ${ }^{96}$

Etanercept is generally less effective than infliximab and adalimumab for ocular indications. It failed to show significant difference in control of uveitis associated with juvenile idiopathic arthritis compared with placebo in a randomized trial. ${ }^{97}$ Baughman et al randomized 18 patients with refractory sarcoid uveitis; 9 received etanercept and 9 were given placebo. The authors found no significant improvement of ocular inflammation with etanercept therapy compared with placebo. ${ }^{98}$

Golimumab has been reported to be effective for the treatment of various uveitides in several series. ${ }^{99-103}$ Calvo-Río et al reported successful control of inflammation in 2 patients with active sarcoid uveitis having previously failed infliximab; however, the follow-up periods were limited to 1 and 9 months for each patient. ${ }^{102}$ Similar findings were reported by Cordero-Coma and coworkers who studied the use of golimumab in uveitis; 2 patients with sarcoid uveitis who previously failed other TNF inhibitor(s) (1 with panuveitis and macular edema, and 1 with intermediate uveitis) achieved complete control of inflammation after 6 months of golimumab therapy. ${ }^{103}$

Due to limited long-term safety and efficacy data, biologic therapy is reserved only as secondary or tertiary treatment of uveitis associated with sarcoidosis. Although rarely, there are multiple reports and series suggesting that anti-TNF agents (infliximab, 104-109 adalimumab, ${ }^{108-110}$ etanercept $^{107,108}$ and certolizumab ${ }^{111}$ ) may cause sarcoidosis-like conditions, including uveitis.

\section{- Treatment of scleritis and external eye diseases}

Non-steroidal anti-inflammatory drugs (NSAIDs) are usually prescribed as a first-line therapy for scleritis. In patients who do not respond to NSAIDs, corticosteroids are typically helpful. Concomitant use of oral corticosteroids and NSAIDs may cause significant gastrointestinal adverse effects. In patients refractory or intolerant to corticosteroids, systemic immunomodulators may be used. Our group reported successful treatment of recalcitrant scleritis with rituximab in $75 \%$ of patients; however, partly due to rarity, none of those patients had scleritis secondary to sarcoidosis. ${ }^{112}$ In one case report, thalidomide was successfully used to treat cutaneous sarcoidosis and nodular scleritis in a patient who failed azathioprine and corticosteroid therapy. ${ }^{113}$ Thalidomide is considered a sedative, hypnotic agent, but also has anti-inflammatory activity. It is under special regulations because it can cause severe congenital defects.

Besides systemic corticosteroid treatment, cutaneous lesions on the eyelids may be treated with intralesional triamcinolone injection ${ }^{36}$ or oral chloroquine. ${ }^{114}$ Conjunctival lesions and KCS may respond to topical cyclosporine eye drops. ${ }^{115,116}$ 


\section{- Treatment of orbital disease}

Orbital inflammation is also typically responsive to oral corticosteroids and/or immunosuppressive agents. In patients with accessible orbital lesions or high suspicion for possible malignancy, biopsy or removal of the lesions should be performed. Along with orbital lesions, strabismus and/or abnormal eyelid position can also be observed. The treatment should initially be maximized with anti-inflammatory therapy. If surgical interventions are required, orbital surgery should be carried out first, followed by strabismus and eyelid surgery, respectively.

\section{- Treatment of ocular complications}

Treatment of ocular complications secondary to ocular inflammation and adverse effects from therapy should not be overlooked. Glaucoma, cataract, epiretinal membrane formation and CME are common. The use of corticosteroids should be minimized by using alternative anti-inflammatory agents in those with significantly elevated IOP. Cataract surgery may be considered when quiescence of intraocular inflammation has been achieved for at least 3 months to avoid postoperative severe inflammatory reaction. Systemic and/or regional corticosteroids may also be given during the perioperative period.

The most important and effective way for the treatment of CME is to control intraocular inflammation with anti-inflammatory therapy. ${ }^{117}$ In patients whose CME persists without active inflammation, intravitreal injections of bevacizumab ${ }^{118}$ or ranibizumab ${ }^{119}$ have been reported as possibly effective therapy to improve vision and macular anatomy. Epiretinal membrane may be surgically removed in those with visually significant puckers. However, treatment of associated inflammation and/or edema should be maximized prior to considering surgery to avoid postoperative inflammation and unnecessary surgery.

\section{Prognosis of ocular sarcoidosis}

Visual prognosis of ocular sarcoidosis may vary depending upon severity and chronicity of eye inflammation, a delay in presentation to a specialist, and ocular complications secondary to uveitis. ${ }^{9}$ A long-term prognostic study of sarcoid uveitis showed that the majority (54\%) of the patients retained vision of better than 20/40 in both eyes, and only $4.6 \%$ had lost vision less than 20/120 in both eyes, at 10 years after the onset of uveitis in a setting of an ophthalmic referral center. ${ }^{120}$ The main causes of irreversible vision loss were glaucoma and chronic maculopathy related to posterior segment inflammation. Thirty-five (47\%) of 75 patients had extraocular involvement at the uveitis onset, with further $17 \%$ during the following 10 years. Fifty-one percent of the patients needed oral corticosteroids, and additional $11 \%$ required immunosuppressive drugs for uveitis treatment. Approximately one-fifth of the patients underwent ocular surgery, including cataract extraction (17\%), trabeculectomy (4\%), retinal detachment repair $(1 \%)$ and epiretinal membrane peel (1\%). The ocular prognosis of sarcoid uveitis seemed unrelated to the presence of extraocular disease. ${ }^{120}$

In Finland, Karma et al studied 281 patients with biopsy proven sarcoidosis. Of those 281 patients, 21 patients with uveitis were followed up regularly. Eight patients (38\%) had a monophasic course of uveitis requiring less than 6 months of treatment, while the remainder 
(13 patients; 62\%) had a relapsing course with multiple recurrences. In the latter group, uveitis was subsequently burned out after several years of treatment in 9 of the 13 patients. ${ }^{121}$ This study also showed that the chest $\mathrm{x}$-ray finding of hilar adenopathy could resolve while the ocular findings persisted. This observation suggests that a subset of patients with "idiopathic" uveitis may have sarcoidosis that is not diagnosable by routine chest x-ray. A 10-year visual prognostic study of 69 patients with peripheral multifocal chorioretinitis revealed that the presence of systemic sarcoidosis had no influence on the risks of developing CME, epiretinal membrane, cataract, glaucoma or optic atrophy. CME was the main cause of decreased vision. The presence of an epiretinal membrane may not necessarily affect final vision. ${ }^{18}$

Although ocular sarcoidosis can present with a sudden onset and a limited course, it is most important to educate the patients of the potential chronicity of ocular inflammation. Longterm follow up and medication compliance are required for treatment success to prevent permanent visual damage from both ocular inflammation and drug-related adverse effects.

\section{References}

1. Crick RP, Hoyle C, Smellie H. The Eyes in Sarcoidosis. Br J Ophthalmol. 1961; 45(7):461-481. [PubMed: 18170695]

2. Rothova A. Ocular involvement in sarcoidosis. Br J Ophthalmol. 2000; 84(1):110-116. [PubMed: 10611110]

3. Atmaca LS, Atmaca-Sonmez P, Idil A, Kumbasar OO, Celik G. Ocular involvement in sarcoidosis. Ocul Immunol Inflamm. 2009; 17(2):91-94. [PubMed: 19412869]

4. Ohara K, Okubo A, Sasaki H, Kamata K. Intraocular manifestations of systemic sarcoidosis. Jpn J Ophthalmol. 1992; 36(4):452-457. [PubMed: 1289622]

5. Heiligenhaus A, Wefelmeyer D, Wefelmeyer E, Rosel M, Schrenk M. The eye as a common site for the early clinical manifestation of sarcoidosis. Ophthalmic Res. 2011; 46(1):9-12. [PubMed: 21099232]

6. Rothova A, Alberts C, Glasius E, Kijlstra A, Buitenhuis HJ, Breebaart AC. Risk factors for ocular sarcoidosis. Doc Ophthalmol. 1989; 72(3-4):287-296. [PubMed: 2625091]

7. Hoover DL, Khan JA, Giangiacomo J. Pediatric ocular sarcoidosis. Surv Ophthalmol. 1986; 30(4): 215-228. [PubMed: 3006270]

8. Rose CD, Wouters CH, Meiorin S, Doyle TM, Davey MP, Rosenbaum JT, Martin TM. Pediatric granulomatous arthritis: an international registry. Arthritis Rheum. 2006; 54(10):3337-3344. [PubMed: 17009307]

9. Dana MR, Merayo-Lloves J, Schaumberg DA, Foster CS. Prognosticators for visual outcome in sarcoid uveitis. Ophthalmology. 1996; 103(11):1846-1853. [PubMed: 8942880]

10. Evans M, Sharma O, LaBree L, Smith RE, Rao NA. Differences in clinical findings between Caucasians and African Americans with biopsy-proven sarcoidosis. Ophthalmology. 2007; 114(2): 325-333. [PubMed: 17123620]

11. Birnbaum AD, Oh FS, Chakrabarti A, Tessler HH, Goldstein DA. Clinical features and diagnostic evaluation of biopsy-proven ocular sarcoidosis. Arch Ophthalmol. 2011; 129(4):409-413. [PubMed: 21482866]

12. Kump LI, Cervantes-Castaneda RA, Androudi SN, Foster CS. Analysis of pediatric uveitis cases at a tertiary referral center. Ophthalmology. 2005; 112(7):1287-1292. [PubMed: 15921752]

13. Smith JA, Mackensen F, Sen HN, Leigh JF, Watkins AS, Pyatetsky D, Tessler HH, Nussenblatt RB, Rosenbaum JT, Reed GF, Vitale S, Smith JR, Goldstein DA. Epidemiology and course of disease in childhood uveitis. Ophthalmology. 2009; 116(8):1544-1551. 1551 e1541. [PubMed: 19651312] 
14. Rodriguez A, Calonge M, Pedroza-Seres M, Akova YA, Messmer EM, D'Amico DJ, Foster CS. Referral patterns of uveitis in a tertiary eye care center. Arch Ophthalmol. 1996; 114(5):593-599. [PubMed: 8619771]

15. Merrill PT, Kim J, Cox TA, Betor CC, McCallum RM, Jaffe GJ. Uveitis in the southeastern United States. Curr Eye Res. 1997; 16(9):865-874. [PubMed: 9288447]

16. Sungur G, Hazirolan D, Bilgin G. Pattern of ocular findings in patients with biopsy-proven sarcoidosis in Turkey. Ocul Immunol Inflamm. 2013; 21(6):455-461. [PubMed: 23909887]

17. Abad S, Meyssonier V, Allali J, Gouya H, Giraudet AL, Monnet D, Parc C, Tenenbaum F, Alberini JL, Grabar S, Pesce F, Rollot F, Sicard D, Dhote R, Blanche P, Brezin AP. Association of peripheral multifocal choroiditis with sarcoidosis: a study of thirty-seven patients. Arthritis Rheum. 2004; 51(6):974-982. [PubMed: 15593175]

18. Ossewaarde-van Norel J, Ten Dam-van Loon N, de Boer JH, Rothova A. Long-term visual prognosis of peripheral multifocal chorioretinitis. Am J Ophthalmol. 2015; 159(4):690-697. [PubMed: 25595670]

19. Rossman MD, Thompson B, Frederick M, Maliarik M, Iannuzzi MC, Rybicki BA, Pandey JP, Newman LS, Magira E, Beznik-Cizman B, Monos D, Group A. HLA-DRB1*1101: a significant risk factor for sarcoidosis in blacks and whites. Am J Hum Genet. 2003; 73(4):720-735. [PubMed: 14508706]

20. Jabs DA, Nussenblatt RB, Rosenbaum JT, Standardization of Uveitis Nomenclature Working G. Standardization of uveitis nomenclature for reporting clinical data. Results of the First International Workshop. Am J Ophthalmol. 2005; 140(3):509-516. [PubMed: 16196117]

21. Zaidi AA, Ying GS, Daniel E, Gangaputra S, Rosenbaum JT, Suhler EB, Thorne JE, Foster CS, Jabs DA, Levy-Clarke GA, Nussenblatt RB, Kempen JH, Systemic Immunosuppressive Therapy for Eye Diseases Cohort S. Hypopyon in patients with uveitis. Ophthalmology. 2010; 117(2):366372. [PubMed: 20006905]

22. Spalton DJ, Sanders MD. Fundus changes in histologically confirmed sarcoidosis. Br J Ophthalmol. 1981; 65(5):348-358. [PubMed: 6166318]

23. Letocha CE, Shields JA, Goldberg RE. Retinal changes in sarcoidosis. Can J Ophthalmol. 1975; 10(2):184-192. [PubMed: 1125843]

24. Gould H, Kaufman HE. Sarcoid of the fundus. Arch Ophthalmol. 1961; 65:453-456. [PubMed: 13707501]

25. Hoogstede HA, Copper AC. A case of macular subretinal neovascularisation in chronic uveitis probably caused by sarcoidosis. Br J Ophthalmol. 1982; 66(8):530-535. [PubMed: 6179536]

26. Khurana RN, Parikh JG, Rao NA. Sarcoid choroiditis simulating birdshot chorioretinopathy. Retin Cases Brief Rep. 2008; 2(4):301-303. [PubMed: 25390597]

27. Delaney P. Neurologic manifestations in sarcoidosis: review of the literature, with a report of 23 cases. Ann Intern Med. 1977; 87(3):336-345. [PubMed: 197863]

28. Phillips YL, Eggenberger ER. Neuro-ophthalmic sarcoidosis. Curr Opin Ophthalmol. 2010; 21(6): 423-429. [PubMed: 20736834]

29. Gass JD, Olson CL. Sarcoidosis with optic nerve and retinal involvement. Arch Ophthalmol. 1976; 94(6):945-950. [PubMed: 938285]

30. Zajicek JP, Scolding NJ, Foster O, Rovaris M, Evanson J, Moseley IF, Scadding JW, Thompson EJ, Chamoun V, Miller DH, McDonald WI, Mitchell D. Central nervous system sarcoidosis-diagnosis and management. QJM. 1999; 92(2):103-117. [PubMed: 10209662]

31. Oie K, Tanigawa K, Suganuma Y, Matsushima Y, Inaba Y. [A case of CNS sarcoidosis -case report of hydrocephalus due to mechanical obstruction secondary to sarcoid granulomata at the outlet of the fourth ventricle (author's transl)]. No Shinkei Geka. 1981; 9(1):75-78. [PubMed: 7231630]

32. Zhang J, Waisbren E, Hashemi N, Lee AG. Visual hallucinations (Charles Bonnet syndrome) associated with neurosarcoidosis. Middle East Afr J Ophthalmol. 2013; 20(4):369-371. [PubMed: 24339694]

33. Yaosaka M, Abe R, Ujiie H, Abe Y, Shimizu H. Unilateral periorbital oedema due to sarcoid infiltration of the eyelid: an unusual presentation of sarcoidosis with facial nerve palsy and parotid gland enlargement. Br J Dermatol. 2007; 157(1):200-202. [PubMed: 17489978] 
34. Pessoa de Souza Filho J, Martins MC, Sant'Anna AE, Coutinho AB, Burnier MN Jr. Rigueiro MP. Eyelid swelling as the only manifestation of ocular sarcoidosis. Ocul Immunol Inflamm. 2005; 13(5):399-402. [PubMed: 16419426]

35. Hall JG, Cohen KL. Sarcoidosis of the eyelid skin. Am J Ophthalmol. 1995; 119(1):100-101. [PubMed: 7825675]

36. Kim YJ, Kim YD. A case of scar sarcoidosis of the eyelid. Korean J Ophthalmol. 2006; 20(4):238240. [PubMed: 17302211]

37. Collins ME, Petronic-Rosic V, Sweiss NJ, Marcet MM. Full-thickness eyelid lesions in sarcoidosis. Case Rep Ophthalmol Med. 2013; 2013:579121. [PubMed: 23762695]

38. Moin M, Kersten RC, Bernardini F, Kulwin DR. Destructive eyelid lesions in sarcoidosis. Ophthal Plast Reconstr Surg. 2001; 17(2):123-125.

39. Behbehani R, Nipper KS, Eagle RC Jr. Bilyk JR. Systemic sarcoidosis manifested as unilateral eyelid retraction. Arch Ophthalmol. 2006; 124(4):599-600. [PubMed: 16606895]

40. Hegab SM, al-Mutawa SA, Sheriff SM. Sarcoidosis presenting as multilobular limbal corneal nodules. J Pediatr Ophthalmol Strabismus. 1998; 35(6):323-326. [PubMed: 9850505]

41. Dithmar S, Waring GO 3rd, Goldblum TA, Grossniklaus HE. Conjunctival deposits as an initial manifestation of sarcoidosis. Am J Ophthalmol. 1999; 128(3):361-362. [PubMed: 10511034]

42. Papadaki TG, Kafkala C, Zacharopoulos IP, Seyedahmadi BJ, Dryja T, Foster CS. Conjunctival non-caseating granulomas in a human immunodeficiency virus (HIV) positive patient attributed to sarcoidosis. Ocul Immunol Inflamm. 2006; 14(5):309-311. [PubMed: 17056466]

43. Manrique Lipa RK, de los Bueis AB, De los Rios JJ, Manrique Lipa RD. Sarcoidosis presenting as acute bulbar follicular conjunctivitis. Clin Exp Optom. 2010; 93(5):363-365. [PubMed: 20718787]

44. Geggel HS, Mensher JH. Cicatricial conjunctivitis in sarcoidosis: recognition and treatment. Ann Ophthalmol. 1989; 21(3):92-94. [PubMed: 2735697]

45. Flach A. Symblepharon in sarcoidosis. Am J Ophthalmol. 1978; 85(2):210-214. [PubMed: 623192]

46. Schilgen G, Sundmacher R, Pomjanski N, Bocking A, Reinecke P, Gabbert HE. [Bilateral large conjunctival tumours as primary manifestation of sarcoidosis--successful treatment with steroiddepot-injections]. Klin Monbl Augenheilkd. 2006; 223(4):326-329. [PubMed: 16639672]

47. Dursun D, Akova YA, Bilezikci B. Scleritis associated with sarcoidosis. Ocul Immunol Inflamm. 2004; 12(2):143-148. [PubMed: 15512984]

48. Heiligenhaus A, Michel D, Koch JM. Nodular scleritis in a patient with sarcoidosis. Br J Ophthalmol. 2003; 87(4):507-508. [PubMed: 12642326]

49. Babu K, Kini R, Mehta R. Scleral nodule and bilateral disc edema as a presenting manifestation of systemic sarcoidosis. Ocul Immunol Inflamm. 2010; 18(3):158-161. [PubMed: 20482388]

50. Dodds EM, Lowder CY, Barnhorst DA, Lavertu P, Caravella LP, White DE. Posterior scleritis with annular ciliochoroidal detachment. Am J Ophthalmol. 1995; 120(5):677-679. [PubMed: 7485375]

51. Riono WP, Hidayat AA, Rao NA. Scleritis: a clinicopathologic study of 55 cases. Ophthalmology. 1999; 106(7):1328-1333. [PubMed: 10406616]

52. Lennarson P, Barney NP. Interstitial keratitis as presenting ophthalmic sign of sarcoidosis in a child. J Pediatr Ophthalmol Strabismus. 1995; 32(3):194-196. [PubMed: 7636703]

53. Siracuse-Lee D, Saffra N. Peripheral ulcerative keratitis in sarcoidosis: a case report. Cornea. 2006; 25(5):618-620. [PubMed: 16783154]

54. Mavrikakis I, Rootman J. Diverse clinical presentations of orbital sarcoid. Am J Ophthalmol. 2007; 144(5):769-775. [PubMed: 17869205]

55. Prabhakaran VC, Saeed P, Esmaeli B, Sullivan TJ, McNab A, Davis G, Valenzuela A, Leibovitch I, Kesler A, Sivak-Callcott J, Hoyama E, Selva D. Orbital and adnexal sarcoidosis. Arch Ophthalmol. 2007; 125(12):1657-1662. [PubMed: 18071118]

56. Demirci H, Christianson MD. Orbital and adnexal involvement in sarcoidosis: analysis of clinical features and systemic disease in 30 cases. Am J Ophthalmol. 2011; 151(6):1074-1080. e1071. [PubMed: 21457924] 
57. Jones BR, Stevenson CJ. Keratoconjunctivitis sicca due to sarcoidosis. Br J Ophthalmol. 1957; 41(3):153-160. [PubMed: 13404198]

58. Chapman KL, Bartley GB, Garrity JA, Gonnering RS. Lacrimal bypass surgery in patients with sarcoidosis. Am J Ophthalmol. 1999; 127(4):443-446. [PubMed: 10218697]

59. Kay DJ, Saffra N, Har-El G. Isolated sarcoidosis of the lacrimal sac without systemic manifestations. Am J Otolaryngol. 2002; 23(1):53-55. [PubMed: 11791250]

60. Kim DS, Korgavkar K, Zahid S, De Lott L, Prabhakar A, Foerster BR, Besirli CG. Vision Loss After Central Retinal Artery Occlusion Secondary to Orbital Sarcoid Mass. Ophthal Plast Reconstr Surg. 2014

61. Jabs DA, Johns CJ. Ocular involvement in chronic sarcoidosis. Am J Ophthalmol. 1986; 102(3): 297-301. [PubMed: 3752193]

62. Shimizu A, Maruyama K, Yokoyama Y, Tsuda S, Ryu M, Nakazawa T. Characteristics of uveitic glaucoma and evaluation of its surgical treatment. Clin Ophthalmol. 2014; 8:2383-2389. [PubMed: 25473265]

63. Herbort CP, Rao NA, Mochizuki M, members of Scientific Committee of First International Workshop on Ocular S. International criteria for the diagnosis of ocular sarcoidosis: results of the first International Workshop On Ocular Sarcoidosis (IWOS). Ocul Immunol Inflamm. 2009; 17(3):160-169. [PubMed: 19585358]

64. Nichols CW, Eagle RC Jr. Yanoff M, Menocal NG. Conjunctival biopsy as an aid in the evaluation of the patient with suspected sarcoidosis. Ophthalmology. 1980; 87(4):287-291. [PubMed: 7393533]

65. Karcioglu ZA, Brear R. Conjunctival biopsy in sarcoidosis. Am J Ophthalmol. 1985; 99(1):68-73. [PubMed: 3966522]

66. Bornstein JS, Frank MI, Radner DB. Conjunctival biopsy in the diagnosis of sarcoidosis. N Engl J Med. 1962; 267:60-64. [PubMed: 13871398]

67. Wertheim MS, Mathers WD, Lim L, Watkins AS, Mackensen F, O'Malley JP, Rosenbaum JT. Non-invasive detection of multinucleated giant cells in the conjunctiva of patients with sarcoidosis by in-vivo confocal microscopy. Ocul Immunol Inflamm. 2006; 14(4):203-206. [PubMed: 16911981]

68. Rose-Nussbaumer J, Li Y, Lin P, Suhler E, Asquith M, Rosenbaum JT, Huang D. Aqueous cell differentiation in anterior uveitis using fourier-domain optical coherence tomography. Invest Ophthalmol Vis Sci. 2015; 56(3):1430-1436. [PubMed: 25650415]

69. Gungor SG, Akkoyun I, Reyhan NH, Yesilirmak N, Yilmaz G. Choroidal thickness in ocular sarcoidosis during quiescent phase using enhanced depth imaging optical coherence tomography. Ocul Immunol Inflamm. 2014; 22(4):287-293. [PubMed: 24912003]

70. Ma J, Chen T, Mandelin J, Ceponis A, Miller NE, Hukkanen M, Ma GF, Konttinen YT. Regulation of macrophage activation. Cell Mol Life Sci. 2003; 60(11):2334-2346. [PubMed: 14625680]

71. Rosenbaum JT, Pasadhika S, Crouser ED, Choi D, Harrington CA, Lewis JA, Austin CR, Diebel TN, Vance EE, Braziel RM, Smith JR, Planck SR. Hypothesis: sarcoidosis is a STAT1-mediated disease. Clin Immunol. 2009; 132(2):174-183. [PubMed: 19464956]

72. Rosenbaum JT, Hessellund A, Phan I, Planck SR, Wilson DJ. The expression of STAT-1 and phosphorylated STAT-1 in conjunctival granulomas. Ocul Immunol Inflamm. 2010; 18(4):261264. [PubMed: 20662656]

73. Rosenbaum JT, Choi D, Wilson DJ, Grossniklaus HE, Harrington CA, Sibley CH, Dailey RA, Ng JD, Steele EA, Czyz CN, Foster JA, Tse D, Alabiad C, Dubovy S, Parekh P, Harris GJ, Kazim M, Patel P, White V, Dolman P, Korn BS, Kikkawa D, Edward DP, Alkatan H, Al-Hussain H, Yeatts RP, Selva D, Stauffer P, Planck SR. Parallel Gene Expression Changes in Sarcoidosis Involving the Lacrimal Gland, Orbital Tissue, or Blood. JAMA Ophthalmol. 2015

74. Sheppard JD, Toyos MM, Kempen JH, Kaur P, Foster CS. Difluprednate $0.05 \%$ versus prednisolone acetate $1 \%$ for endogenous anterior uveitis: a phase III, multicenter, randomized study. Invest Ophthalmol Vis Sci. 2014; 55(5):2993-3002. [PubMed: 24677110]

75. Khurana RN, Porco TC. Efficacy and Safety of Dexamethasone Intravitreal Implant for Persistent Uveitic Cystoid Macular Edema. Retina. 2015 
76. Ozkok A, Saleh OA, Sigford DK, Heroman JW, Schaal S. THE OMAR STUDY: Comparison of Ozurdex and Triamcinolone Acetonide for Refractory Cystoid Macular Edema in Retinal Vein Occlusion. Retina. 2015

77. Jaffe GJ, Martin D, Callanan D, Pearson PA, Levy B, Comstock T, Fluocinolone Acetonide Uveitis Study G. Fluocinolone acetonide implant (Retisert) for noninfectious posterior uveitis: thirty-four-week results of a multicenter randomized clinical study. Ophthalmology. 2006; 113(6): 1020-1027. [PubMed: 16690128]

78. Goldstein DA, Godfrey DG, Hall A, Callanan DG, Jaffe GJ, Pearson PA, Usner DW, Comstock TL. Intraocular pressure in patients with uveitis treated with fluocinolone acetonide implants. Arch Ophthalmol. 2007; 125(11):1478-1485. [PubMed: 17923537]

79. Multicenter Uveitis Steroid Treatment Trial Research G. Sugar EA, Holbrook JT, Kempen JH, Burke AE, Drye LT, Thorne JE, Louis TA, Jabs DA, Altaweel MM, Frick KD. Cost-effectiveness of fluocinolone acetonide implant versus systemic therapy for noninfectious intermediate, posterior, and panuveitis. Ophthalmology. 2014; 121(10):1855-1862. [PubMed: 24908205]

80. Dev S, McCallum RM, Jaffe GJ. Methotrexate treatment for sarcoid-associated panuveitis. Ophthalmology. 1999; 106(1):111-118. [PubMed: 9917790]

81. Bhat P, Cervantes-Castaneda RA, Doctor PP, Anzaar F, Foster CS. Mycophenolate mofetil therapy for sarcoidosis-associated uveitis. Ocul Immunol Inflamm. 2009; 17(3):185-190. [PubMed: 19585361]

82. Walton RC, Nussenblatt RB, Whitcup SM. Cyclosporine therapy for severe sight-threatening uveitis in children and adolescents. Ophthalmology. 1998; 105(11):2028-2034. [PubMed: 9818601]

83. Murphy CC, Greiner K, Plskova J, Duncan L, Frost NA, Forrester JV, Dick AD. Cyclosporine vs tacrolimus therapy for posterior and intermediate uveitis. Arch Ophthalmol. 2005; 123(5):634 641. [PubMed: 15883282]

84. Jabs DA, Rosenbaum JT, Foster CS, Holland GN, Jaffe GJ, Louie JS, Nussenblatt RB, Stiehm ER, Tessler H, Van Gelder RN, Whitcup SM, Yocum D. Guidelines for the use of immunosuppressive drugs in patients with ocular inflammatory disorders: recommendations of an expert panel. Am J Ophthalmol. 2000; 130(4):492-513. [PubMed: 11024423]

85. Gangaputra S, Newcomb CW, Liesegang TL, Kacmaz RO, Jabs DA, Levy-Clarke GA, Nussenblatt RB, Rosenbaum JT, Suhler EB, Thorne JE, Foster CS, Kempen JH, Systemic Immunosuppressive Therapy for Eye Diseases Cohort S. Methotrexate for ocular inflammatory diseases. Ophthalmology. 2009; 116(11):2188-2198. e2181. [PubMed: 19748676]

86. Daniel E, Thorne JE, Newcomb CW, Pujari SS, Kacmaz RO, Levy-Clarke GA, Nussenblatt RB, Rosenbaum JT, Suhler EB, Foster CS, Jabs DA, Kempen JH. Mycophenolate mofetil for ocular inflammation. Am J Ophthalmol. 2010; 149(3):423-432. e421-422. [PubMed: 20042178]

87. Pasadhika S, Kempen JH, Newcomb CW, Liesegang TL, Pujari SS, Rosenbaum JT, Thorne JE, Foster CS, Jabs DA, Levy-Clarke GA, Nussenblatt RB, Suhler EB. Azathioprine for ocular inflammatory diseases. Am J Ophthalmol. 2009; 148(4):500-509. e502. [PubMed: 19570522]

88. Kacmaz RO, Kempen JH, Newcomb C, Daniel E, Gangaputra S, Nussenblatt RB, Rosenbaum JT, Suhler EB, Thorne JE, Jabs DA, Levy-Clarke GA, Foster CS. Cyclosporine for ocular inflammatory diseases. Ophthalmology. 2010; 117(3):576-584. [PubMed: 20031223]

89. Jaffe GJ, Thorne JE, Scales D, Franco P, Tari SR, Camez A, Song AP, Kron M, BarisaniAsenbauer T, Dick AD. Adalimumab in patients with active, non-infectious uveitis requiring highdose corticosteroids: the VISUAL-1 trial. ARVO 2015 Annual Meeting Abstracts by Scientific Section/Group - Immunology/Microbiology. 2015:73-74.

90. Suhler EB, Smith JR, Wertheim MS, Lauer AK, Kurz DE, Pickard TD, Rosenbaum JT. A prospective trial of infliximab therapy for refractory uveitis: preliminary safety and efficacy outcomes. Arch Ophthalmol. 2005; 123(7):903-912. [PubMed: 16009830]

91. Suhler EB, Smith JR, Giles TR, Lauer AK, Wertheim MS, Kurz DE, Kurz PA, Lim L, Mackensen F, Pickard TD, Rosenbaum JT. Infliximab therapy for refractory uveitis: 2-year results of a prospective trial. Arch Ophthalmol. 2009; 127(6):819-822. [PubMed: 19506209] 
92. Pritchard C, Nadarajah K. Tumour necrosis factor alpha inhibitor treatment for sarcoidosis refractory to conventional treatments: a report of five patients. Ann Rheum Dis. 2004; 63(3):318320. [PubMed: 14962969]

93. Doty JD, Mazur JE, Judson MA. Treatment of sarcoidosis with infliximab. Chest. 2005; 127(3): 1064-1071. [PubMed: 15764796]

94. Benitez-del-Castillo JM, Martinez-de-la-Casa JM, Pato-Cour E, Mendez-Fernandez R, LopezAbad C, Matilla M, Garcia-Sanchez J. Long-term treatment of refractory posterior uveitis with anti-TNFalpha (infliximab). Eye (Lond). 2005; 19(8):841-845. [PubMed: 15389273]

95. Erckens RJ, Mostard RL, Wijnen PA, Schouten JS, Drent M. Adalimumab successful in sarcoidosis patients with refractory chronic non-infectious uveitis. Graefes Arch Clin Exp Ophthalmol. 2012; 250(5):713-720. [PubMed: 22119879]

96. Suhler EB, Lowder CY, Goldstein DA, Giles T, Lauer AK, Kurz PA, Pasadhika S, Lee ST, de Saint Sardos A, Butler NJ, Tessler HH, Smith JR, Rosenbaum JT. Adalimumab therapy for refractory uveitis: results of a multicentre, open-label, prospective trial. Br J Ophthalmol. 2013; 97(4):481-486. [PubMed: 23376607]

97. Smith JA, Thompson DJ, Whitcup SM, Suhler E, Clarke G, Smith S, Robinson M, Kim J, Barron KS. A randomized, placebo-controlled, double-masked clinical trial of etanercept for the treatment of uveitis associated with juvenile idiopathic arthritis. Arthritis Rheum. 2005; 53(1):18-23. [PubMed: 15696578]

98. Baughman RP, Lower EE, Bradley DA, Raymond LA, Kaufman A. Etanercept for refractory ocular sarcoidosis: results of a double-blind randomized trial. Chest. 2005; 128(2):1062-1047. [PubMed: 16100213]

99. William M, Faez S, Papaliodis GN, Lobo AM. Golimumab for the treatment of refractory juvenile idiopathic arthritis-associated uveitis. J Ophthalmic Inflamm Infect. 2012; 2(4):231-233. [PubMed: 22581347]

100. Cordero-Coma M, Salom D, Diaz-Llopis M, Lopez-Prats MJ, Calleja S. Golimumab for uveitis. Ophthalmology. 2011; 118(9):1892. e1893-1894. [PubMed: 21889663]

101. Miserocchi E, Modorati G, Pontikaki I, Meroni P, Gerloni V. Golimumab treatment for complicated uveitis. Clin Exp Rheumatol. 2013; 31(2):320-321. [PubMed: 23331715]

102. Calvo-Rio V, de la Hera D, Blanco R, Beltran-Catalan E, Loricera J, Canal J, Ventosa J, Cifrian JM, Ortiz-Sanjuan F, Rueda-Gotor J, Gonzalez-Vela MC, Gonzalez-Lopez M, Gonzalez-Gay MA. Golimumab in uveitis previously treated with other anti-TNF-alpha drugs: a retrospective study of three cases from a single centre and literature review. Clin Exp Rheumatol. 2014; 32(6): 864-868. [PubMed: 25288110]

103. Cordero-Coma M, Calvo-Rio V, Adan A, Blanco R, Alvarez-Castro C, Mesquida M, Calleja S, Gonzalez-Gay MA, Ruiz de Morales JG. Golimumab as rescue therapy for refractory immunemediated uveitis: a three-center experience. Mediators Inflamm. 2014; 2014:717598. [PubMed: 24976689]

104. Izzi S, Francesconi F, Visca P, Altieri A, De Mutiis C, Trevisan G, Bonifati C. Pulmonary sarcoidosis in a patient with psoriatic arthritis during infliximab therapy. Dermatol Online J. 2010; 16(5):16. [PubMed: 20492833]

105. Olivier A, Gilson B, Lafontaine S, Pautot JX, Bindi P. [Pulmonary and renal involvement in a TNFalpha antagonist drug-induced sarcoidosis]. Rev Med Interne. 2012; 33(5):e25, 27. [PubMed: 21592629]

106. Takahashi H, Kaneta K, Honma M, Ishida-Yamamoto A, Ashida T, Kohgo Y, Ohsaki Y, Iizuka H. Sarcoidosis during infliximab therapy for Crohn's disease. J Dermatol. 2010; 37(5):471-474. [PubMed: 20536653]

107. Clementine RR, Lyman J, Zakem J, Mallepalli J, Lindsey S, Quinet R. Tumor necrosis factoralpha antagonist-induced sarcoidosis. J Clin Rheumatol. 2010; 16(6):274-279. [PubMed: 20808167]

108. Daien CI, Monnier A, Claudepierre P, Constantin A, Eschard JP, Houvenagel E, Samimi M, Pavy S, Pertuiset E, Toussirot E, Combe B, Morel J, Club Rhumatismes et I. Sarcoid-like granulomatosis in patients treated with tumor necrosis factor blockers: 10 cases. Rheumatology (Oxford). 2009; 48(8):883-886. [PubMed: 19423648] 
109. Dhaille F, Viseux V, Caudron A, Dadban A, Tribout C, Boumier P, Clabaut A, Lok C. Cutaneous sarcoidosis occurring during anti-TNF-alpha treatment: report of two cases. Dermatology. 2010; 220(3):234-237. [PubMed: 20185892]

110. Metyas SK, Tadros RM, Arkfeld DG. Adalimumab-induced noncaseating granuloma in the bone marrow of a patient being treated for rheumatoid arthritis. Rheumatol Int. 2009; 29(4):437-439. [PubMed: 18762943]

111. Moisseiev E, Shulman S. Certolizumab-induced uveitis: a case report and review of the literature. Case Rep Ophthalmol. 2014; 5(1):54-59. [PubMed: 24707273]

112. Suhler EB, Lim LL, Beardsley RM, Giles TR, Pasadhika S, Lee ST, de Saint Sardos A, Butler NJ, Smith JR, Rosenbaum JT. Rituximab therapy for refractory scleritis: results of a phase I/II doseranging, randomized, clinical trial. Ophthalmology. 2014; 121(10):1885-1891. [PubMed: 24953794]

113. Huddleston SM, Houser KH, Walton RC. Thalidomide for recalcitrant nodular scleritis in sarcoidosis. JAMA Ophthalmol. 2014; 132(11):1377-1379. [PubMed: 25078792]

114. Brownstein S, Liszauer AD, Carey WD, Nicolle DA. Sarcoidosis of the eyelid skin. Can J Ophthalmol. 1990; 25(5):256-259. [PubMed: 2207873]

115. Oh JY, Wee WR. Cyclosporine for conjunctival sarcoidosis. Ophthalmology. 2008; 115(1):222. [PubMed: 18166429]

116. Akpek EK, Ilhan-Sarac O, Green WR. Topical cyclosporin in the treatment of chronic sarcoidosis of the conjunctiva. Arch Ophthalmol. 2003; 121(9):1333-1335. [PubMed: 12963621]

117. Pasadhika S, Smith JR. Treatment of uveitic macular edema: an overview and update. Ophthalmology International. 2008:97-103. Spring.

118. Cordero Coma M, Sobrin L, Onal S, Christen W, Foster CS. Intravitreal bevacizumab for treatment of uveitic macular edema. Ophthalmology. 2007; 114(8):1574-1579. e1571. [PubMed: 17363060]

119. Acharya NR, Hong KC, Lee SM. Ranibizumab for refractory uveitis-related macular edema. Am J Ophthalmol. 2009; 148(2):303-309. e302. [PubMed: 19427988]

120. Edelsten C, Pearson A, Joynes E, Stanford MR, Graham EM. The ocular and systemic prognosis of patients presenting with sarcoid uveitis. Eye (Lond). 1999; 13:748-753. Pt 6. [PubMed: 10707138]

121. Karma A, Huhti E, Poukkula A. Course and outcome of ocular sarcoidosis. Am J Ophthalmol. 1988; 106(4):467-472. [PubMed: 3177566] 


\section{Key points}

- Ocular sarcoidosis can involve any part of the eye and its adnexal tissues.

- The most common ocular manifestations are uveitis, dry eye and conjunctival nodules.

- Ocular involvement is the presenting symptom in approximately $20-30 \%$ of patients with sarcoidosis.

- Multi-disciplinary approaches are required to achieve the best treatment outcomes for both ocular and systemic manifestations.

- With appropriate treatment, visual prognosis is generally good. 

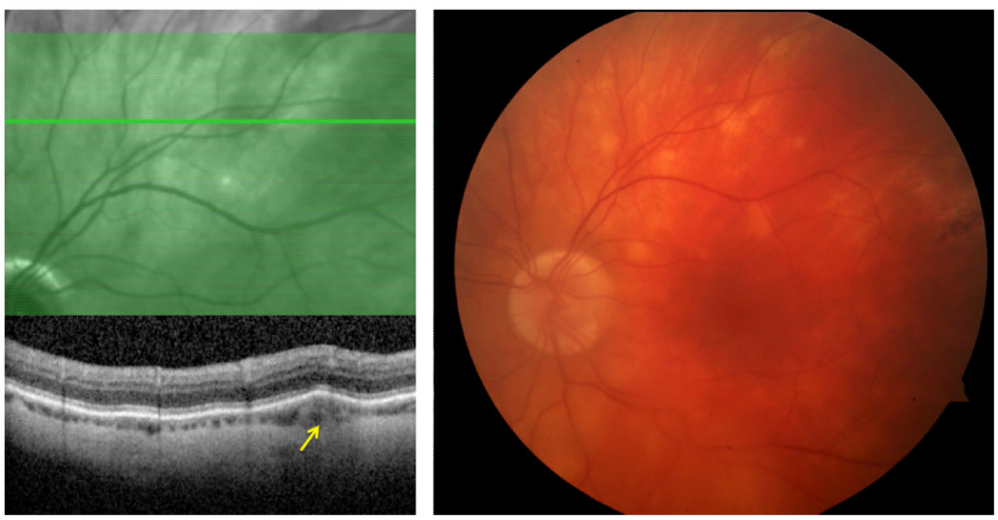

Figure 1.

(Right) Color fundus photograph of a 59-year-old male patient with multifocal choroiditis secondary to sarcoidosis demonstrates multiple round, creamy, subretinal lesions in the superotemporal quadrant of the left eye; (Left) optical coherence tomography study through the lesion showed that the lesion primarily involves the choroid (arrow). 


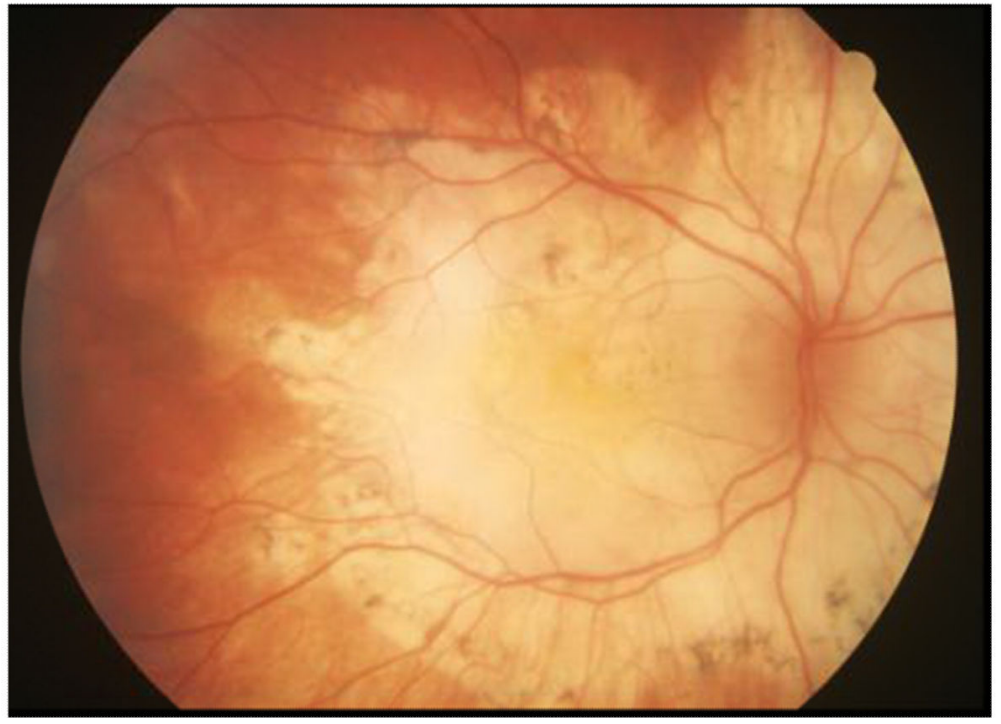

Figure 2.

Color fundus photograph of a 56-year-old male patient with extensive chorioretinal atrophy and scar secondary to longstanding involvement from ocular sarcoidosis. 


\section{Table 1}

Examples of clinical manifestations of ocular sarcoidosis

\begin{tabular}{|l|l|}
\hline \multicolumn{1}{|c|}{ Ocular structures } & \multicolumn{1}{c|}{ Ophthalmic manifestations } \\
\hline - Eyelids & $\begin{array}{l}\text { Eyelid granuloma, madarosis (loss of eyelashes), } \\
\text { poliosis (whitening of lashes), entropion, trichiasis, } \\
\text { lagoghthalmos (if associated with facial palsy) }\end{array}$ \\
\hline - Conjunctiva & $\begin{array}{l}\text { Conjunctival nodules or granuloma, conjunctivitis, } \\
\text { symblepharon, conjunctival cicatrization }\end{array}$ \\
\hline - Episclera/sclera & Episcleritis, scleritis \\
\hline - Cornea & $\begin{array}{l}\text { Peripheral ulcerative keratitis, interstitial keratitis, } \\
\text { exposure keratopathy, band keratopathy }\end{array}$ \\
\hline - Trabecular meshwork and anterior \\
chamber angle & $\begin{array}{l}\text { Trabecular granuloma, peripheral anterior } \\
\text { synechiae, ocular hypertension, glaucoma }\end{array}$ \\
\hline - Iris & $\begin{array}{l}\text { Anterior uveitis (iritis), iris nodules/granuloma, } \\
\text { posterior synechiae, pupillary abnormalities }\end{array}$ \\
\hline - Lens & Cataract \\
\hline - Pars plana/vitreous & Intermediate uveitis \\
\hline - Retina & Retinitis, retinal vasculitis, macular edema \\
\hline - Choroid & Choroiditis, granuloma \\
\hline - Optic nerve & $\begin{array}{l}\text { Papillitis, papilledema (increased intracranial } \\
\text { pressure due to neurosarcoid), granuloma, optic } \\
\text { neuropathy (compressive or infiltrative), optic } \\
\text { atrophy }\end{array}$ \\
\hline - Lacrimal gland & $\begin{array}{l}\text { Granuloma, dacryoadenitis, keratoconjunctivitis } \\
\text { sicca (dry eye) }\end{array}$ \\
\hline - Nasolacrimal drainage system & Nasolacrimal duct obstruction \\
\hline - Extraocular muscles and other orbital tissues & $\begin{array}{l}\text { Granuloma, strabismus, proptosis, optic nerve } \\
\text { compression }\end{array}$ \\
\hline - Intracranial lesions involving visual pathway & $\begin{array}{l}\text { Decreased vision, visual field defects, abnormal } \\
\text { pupillary response, abnormal eye movement }\end{array}$ \\
\hline & \\
\hline
\end{tabular}

Clin Chest Med. Author manuscript; available in PMC 2016 December 01. 
Table 2

\section{Summary from International Criteria for the Diagnosis of Ocular Sarcoidosis}

\begin{tabular}{|c|c|}
\hline \multicolumn{2}{|c|}{ Ocular signs suggestive for ocular sarcoidosis } \\
\hline \multicolumn{2}{|c|}{ 1. Mutton-flat keratic precipitates and/or iris nodules } \\
\hline \multicolumn{2}{|c|}{ 2. Trabecular meshwork nodules and/or tent-shaped peripheral anterior synechiae } \\
\hline \multicolumn{2}{|c|}{ 3. Snowballs or string of pearls in the vitreous } \\
\hline \multicolumn{2}{|c|}{ 4. Active or inactive multiple chorioretinal peripheral lesions } \\
\hline \multicolumn{2}{|c|}{ 5. Nodular and/or segmental periphlebitis and/or macroaneurysms in an inflamed eye } \\
\hline \multicolumn{2}{|c|}{ 6. Optic disc nodule(s)/granuloma(s) and/or solitary choroidal nodule } \\
\hline \multicolumn{2}{|l|}{ 7. Bilateral involvement } \\
\hline \multicolumn{2}{|c|}{ Laboratory investigations in patients suspected for ocular sarcoidosis } \\
\hline \multicolumn{2}{|c|}{$\begin{array}{l}\text { 1. Negative tuberculin test in a BCG vaccinated patient or with previous positive PPD (or Mantoux) } \\
\text { skin test }\end{array}$} \\
\hline \multicolumn{2}{|c|}{ 2. Elevated serum level of angiotensin converting enzyme (ACE) and/or lysozyme } \\
\hline \multicolumn{2}{|c|}{ 3. Chest $\mathrm{x}$-ray for bilateral symmetric hilar adenopathy } \\
\hline \multicolumn{2}{|c|}{$\begin{array}{l}\text { 4. Abnormal liver enzyme tests (any } 2 \text { of alkaline phosphatase, aspartate aminotransferase (AST), } \\
\text { alanine aminotransferase (ALT), lactate dehydrogenase (LDH) or gamma-glutamyl transferase } \\
\text { (GGT)) }\end{array}$} \\
\hline \multicolumn{2}{|c|}{ 5. Chest computerized tomography in patients with negative chest $\mathrm{x}$-ray } \\
\hline \multicolumn{2}{|c|}{ Diagnostic criteria and terminologies for ocular sarcoidosis } \\
\hline Definite ocular sarcoidosis & Biopsy-proven with a compatible uveitis \\
\hline Presumed ocular sarcoidosis & $\begin{array}{l}\text { Biopsy not performed; bilateral hilar adenopathy (BHL) with compatible } \\
\text { uveitis }\end{array}$ \\
\hline Probable ocular sarcoidosis & $\begin{array}{l}\text { Biopsy not performed and no BHL detected; presence of } 3 \text { suggestive } \\
\text { ocular signs and } 2 \text { positive above laboratory tests }\end{array}$ \\
\hline Possible ocular sarcoidosis & $\begin{array}{l}\text { Biopsy negative; presence of } 4 \text { suggestive ocular signs and } 2 \text { positive } \\
\text { above laboratory tests }\end{array}$ \\
\hline
\end{tabular}

Adapted Herbort CP, Rao NA, Mochizuki M, members of Scientific Committee of First International Workshop on Ocular S. International criteria for the diagnosis of ocular sarcoidosis: results of the first International Workshop On Ocular Sarcoidosis (IWOS). Ocul Immunol Inflamm. 2009;17(3):160-169; with permission. 
Table 3

Examples of steroid-sparing systemic immunosuppressive agents that may be used for the treatment of ocular sarcoidosis

\begin{tabular}{|l|c|c|}
\hline \multicolumn{1}{|c|}{ Medication } & Dose & Expected onset of action \\
\hline Antimetabolites & $7.5-25 \mathrm{mg} / \mathrm{week} \mathrm{PO}, \mathrm{SQ}$ or IM & $2-12$ weeks \\
\hline - Methotrexate & $500-1500 \mathrm{mg}$ PO twice daily & $2-12$ weeks \\
\hline - Mycophenolate mofetil & $1-4 \mathrm{mg} / \mathrm{kg} /$ day PO daily & $4-12$ weeks \\
\hline - Azathioprine & \multicolumn{3}{|c|}{} \\
\hline Calcineurin inhibitors & $2.5-10 \mathrm{mg} / \mathrm{kg} /$ day PO twice daily & $2-6$ weeks \\
\hline - Cyclosporine & $0.15-0.30 \mathrm{mg} / \mathrm{kg} /$ day PO & $2-6$ weeks \\
\hline - Tacrolimus
\end{tabular}

$\mathrm{IM}=$ intramuscularly; $\mathrm{PO}=$ orally; $\mathrm{SQ}=$ subcutaneously

Adapted from Jabs DA, Rosenbaum JT, Foster CS, Holland GN, Jaffe GJ, Louie JS, Nussenblatt RB, Stiehm ER, Tessler H, Van Gelder RN, Whitcup SM, Yocum D. Guidelines for the use of immunosuppressive drugs in patients with ocular inflammatory disorders: recommendations of an expert panel. Am J Ophthalmol. 2000;130(4):492-513; with permission. 